\title{
Sorption of Cesium and Strontium on Montmorillonite and Kaolinite*
}

\author{
By H. N. ERten ${ }^{1}$, S. Aksoyoglu ${ }^{2}$, S. HATIPOglu ${ }^{2}$ and H. GOKTURK 2 , \\ 1 Department of Chemistry, Bilkent University Ankara-Turkey \\ 2 Department of Chemistry, Middle East Technical University, Ankara-Turkey
}

(Received September 12, 1987; revised January 11, 1988)

\section{Clays/Sorption/Fission products/Batch method / Distribution ratios}

\section{Summary}

Sorption characteristics of $\mathrm{Cs}^{+}$and $\mathrm{Sr}^{++}$on montmorillonite and kaolinite type clays and soil fractions from various regions of Turkey were studied using the batch method. ${ }^{137} \mathrm{Cs}$ and ${ }^{90} \mathrm{Sr}$ were used as tracers. Concentrations of $\mathrm{Cs}^{+}$and $\mathrm{Sr}^{++}$ions ranged from $10^{-8}$ to $10^{-2} \mathrm{~mol} / \mathrm{l}$; natural ground water was used and the grain size of the solid particles was $<20 \mu \mathrm{m}$. Equilibrium was reached in $4-7$ days for $\mathrm{Cs}^{+}$and $7-11$ days for $\mathrm{Sr}^{++}$. The distribution coefficient, $R_{D}$, increased with decreasing grain size, suggesting mainly a surface phenomenon. The sorption isotherms were non-linear suggesting at least two different sorption processes. The sorption was found to be predominantly reversible. $\mathrm{Cs}^{+}$was sorbed much stronger than $\mathrm{Sr}^{++}$in all samples.

\section{Introduction}

Storage of radioactive wastes in underground repositories necessitates information on the mobility and chemical behaviour of the individual radionuclides in geologic environments.

The fission products ${ }^{137} \mathrm{Cs}\left(t_{1 / 2}=30.2 \mathrm{y}\right)$ and ${ }^{90} \mathrm{Sr}$ $\left(t_{1 / 2}=28.8 \mathrm{y}\right)$, are the principle sources of radioactivity during the first 1000 years, due to their long half-lives and high fission yields. They may be discharged into the environment from nuclear power plants, nuclear weapon tests and accidents occuring at reprocessing plants.

The interaction of $\mathrm{Cs}^{+}$and $\mathrm{Sr}^{2+}$ ions with various soil fractions plays an important role in their dispersal to the environment and thus in the extent of contamination of underground waters. Of the various soil fractions, clays are the most important components in such interactions.

The sorption properties of several radionuclides on various sorbents has been the subject of many recent investigations [ $1-9]$.

In this work, the sorption characteristics of $\mathrm{Cs}^{+}$and $\mathrm{Sr}^{2+}$ on two types of clays and one soil fraction from Turkey were studied, in line with plans to establish a radioactive waste treatment and storage facility.

\section{Experimental}

Kaolinite and montmorillonite type clays from two regions of Turkey (Mihaliccik and Resadiye) and soil fractions from Sarayköy were used. Neutron activation analysis, Fourier Transform Infrared (FTIR) and X-Ray Diffraction Spectrometry were used to elucidate the structure of the clay and soil fractions. Particles were separated into various size fractions by a combination of wet sieving followed by sedimentation using an Andreasen pipette.

The sorption experiments were carried out using groundwater from the Middle East Technical University (METU) and Sarayköy Ground Water (SGW). The water samples were filtered through $0.22 \mu \mathrm{m}$ Seitz bacteriological filters before use. For the composition see Table 1 .

Since ${ }^{90} \mathrm{Sr}$ and ${ }^{137} \mathrm{Cs}$ constitute the principle radiocontaminants from relatively fresh spent uranium fuels, $\mathrm{Sr}^{2+}$ and $\mathrm{Cs}^{+}$were first chosen for sorption studies. The initial concentrations ranged from $10^{-8}$ to $10^{-2} \mathrm{~mol} / 1$. ${ }^{137} \mathrm{Cs}$ and ${ }^{90} \mathrm{Sr}$ were obtained from the Radiochemical Center, Amersham.

The sorption and desorption experiments were carried out using the batch method. About $100 \mathrm{mg}$ of clay or soil samples were kept in contact with $10 \mathrm{ml}$ of groundwater in closed centrifuge tubes. They were shaken for four days in the pretreatment step in order to equilibrate the clay samples with the groundwater prior to the sorption experiments. The phases were separated by centrifuging at $6000 \mathrm{rpm}$ for 30 minutes. After addition of $10 \mathrm{ml} \mathrm{Cs}$ or $\mathrm{Sr}$ solution the samples were shaken again and centrifuged. The change of the adsorbate concentration in the solution was determined radiochemically.

The distribution coefficient, $\mathbf{R}_{\mathbf{D}}$, was calculated from:

$$
R_{D}=\frac{[C]_{s}}{[C]_{l}}=\frac{V \cdot A^{0}-A(V+\Delta V)}{A \cdot W_{s}}
$$

where,

$[C]_{s}=$ Concentration of the cation in the solid phase after sorption (mmol/g).

$[C]_{l}=$ Concentration of the cation in the solution after sorption (mmol $/ \mathrm{ml})$.

$A_{0}=$ Initial activity of the solution (cpm).

$A \quad=$ Activity of the solution after sorption (cpm).

$V \quad=$ Volume of solution added $(\mathrm{ml})$.

$\Delta V=$ Volume of liquid remaining after pretreatment and decantation ( $\mathrm{ml}$ ).

$w_{s} \quad=$ Mass of solid material ( $\mathrm{g}$ ).

For desorption studies $10 \mathrm{ml}$ of groundwater was added to the sample tube following the adsorption step, shaken for seven days, centrifuged and decanted. The activity of the liquid phase was then determined.

Similar expressions as above were used for the calculation of $R_{D}$ values for desorption studies. Correction for the remaining activity from the adsorption step was

\footnotetext{
* Supported in part by the International A tomic Energy Agency Vienna, and by the Turkish Atomic Energy Authority, Ankara.
} 
Table 1. Chemical analysis of water samples used in the sorption studies

\begin{tabular}{|c|c|c|c|c|c|c|c|c|}
\hline \multirow[t]{2}{*}{ Water samples } & \multicolumn{7}{|c|}{ Ion concentrations (mg/l) } & \multirow[t]{2}{*}{$\mathrm{pH}$} \\
\hline & $\mathrm{Na}^{+}$ & $\mathrm{K}^{+}$ & $\mathrm{Ca}^{++}$ & $\mathrm{Ma}^{++}$ & $\mathrm{Cl}^{-}$ & $\mathrm{HCO}_{3}^{-}$ & $\mathrm{SO}_{4}^{=}$ & \\
\hline \multicolumn{9}{|c|}{ METU Groundwater } \\
\hline No Pretreatment & 1.10 & 1.11 & 0.80 & 0.34 & 0.60 & 35.00 & 0.30 & 7.9 \\
\hline $\begin{array}{l}\text { Pretreatment } \\
\text { (Mihalliccik Clay) }\end{array}$ & 197.00 & 4.50 & 8.20 & 14.90 & 19.20 & 393.00 & 56.90 & 8.4 \\
\hline $\begin{array}{l}\text { Pretreatment } \\
\text { (Resadiye Clay) }\end{array}$ & 336.00 & 13.40 & 13.90 & 81.40 & 7.40 & 434.00 & 94.80 & 8.7 \\
\hline \multicolumn{9}{|l|}{$\begin{array}{l}\text { Sarayköy } \\
\text { Groundwater }\end{array}$} \\
\hline No Pretreatment & 102.00 & 4.61 & 23.30 & 39.00 & 43.00 & 317.00 & 73.70 & 8.8 \\
\hline $\begin{array}{l}\text { Pretreatment } \\
\text { (Sarayköy Soil) }\end{array}$ & 103.00 & 7.20 & 46.00 & 27.00 & 41.70 & 137.00 & 76.10 & 9.1 \\
\hline
\end{tabular}

made by determining the volume of liquid remaining after adsorption and decantation. The experimental procedure and the equations are described in more detail elsewhere [10].

\section{Results and discussion}

Chemical analysis of water samples used in the experiments as well as those resulting from pretreatment with various clay and soil fractions, were carried out using atomic absorption spectrometry. The results together with $\mathrm{pH}$ values are given in Table 1 . Since the radioactive waste treatment and storage facility is planned to be established in Ankara, using METU groundwater was throught to be appropriate for sorption studies. Further- more, since clay and soil samples were pretreated with the groundwater prior to sorption, the compositions of the different groundwaters after pretreatment are similar.

Neutron activation analysis was used for the determination of the concentrations of 13 elements in clay samples from four different regions. Resadiye clay (montmorillonite) as well as Küre clay and Sindirgi clay (both kaolinite) were found to contain considerable amounts of $\mathrm{Na}, \mathrm{Ba}$ and $\mathrm{Fe}$. Detailed results are given in ref. 11 .

FTIR-Spectrometry and X-ray diffraction studies established the structure of the clay samples as kaolinite (Mihaliccik Clay) and montmorillonite (Resadiye Clay) types.

The principle constituents of Sarayköy soil fractions were identified as quartz, calcite, halloysite and chlorite.

The results of sorption kinetics is illustrated in Fig. 1

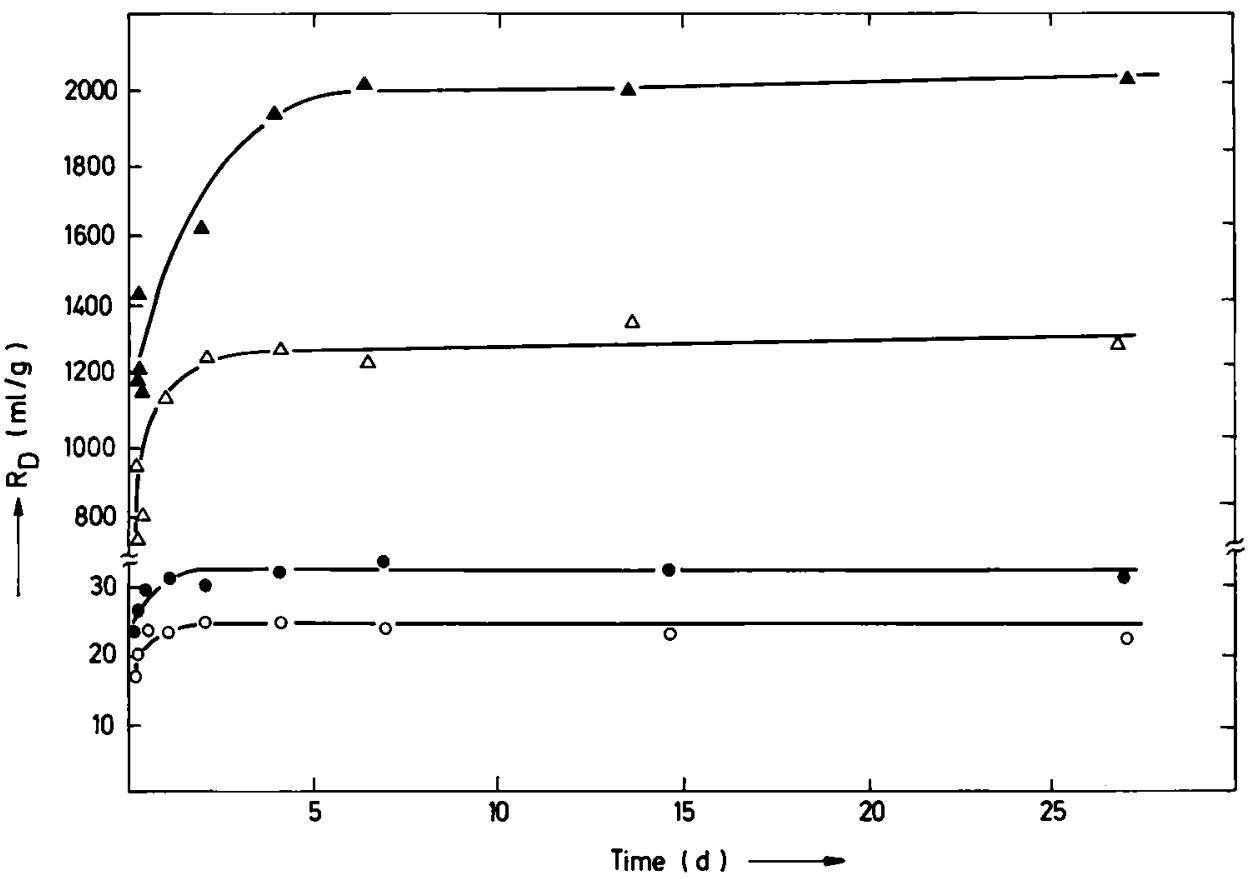

Fig. 1. Sorption kinetics of cesium. Change of $R_{D}$ with contact time for Mihalliccik Clay (Kaolinite).

- Particle size $<10 \mu \mathrm{m} \quad[\mathrm{Cs}]^{0}=1.01 \times 10^{-5} \mathrm{mmol} / \mathrm{ml}$

- Particle size $=10-20 \mu \mathrm{m}[\mathrm{Cs}]^{0}=1.01 \times 10^{-5} \mathrm{mmol} / \mathrm{ml}$.
- Particle size $<10 \mu \mathrm{m} \quad[\mathrm{Cs}]^{0}=1.19 \times 10^{-8} \mathrm{mmol} / \mathrm{ml}$. $\triangle$ Particle size $=10-20 \mu \mathrm{m}[\mathrm{Cs}]^{0}=1.19 \times 10^{-8} \mathrm{mmol} / \mathrm{ml}$. 


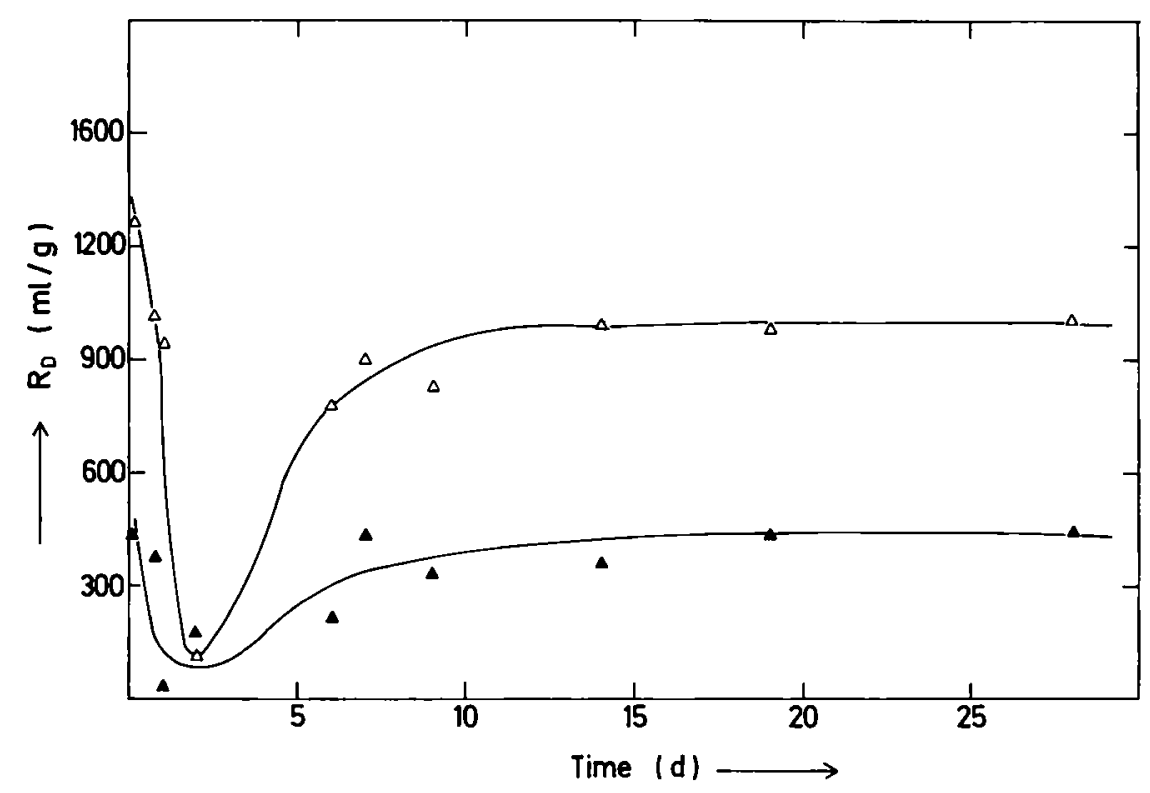

Fig. 2. Desorption kinetics of strontium. Change of $R_{D}$ with contact time, following adsorption, for Rasadiye clay (Montmorillonite).

- Particle size $<10 \mu \mathrm{m}$

$\triangle$ Particle size $=10-20 \mu \mathrm{m}$

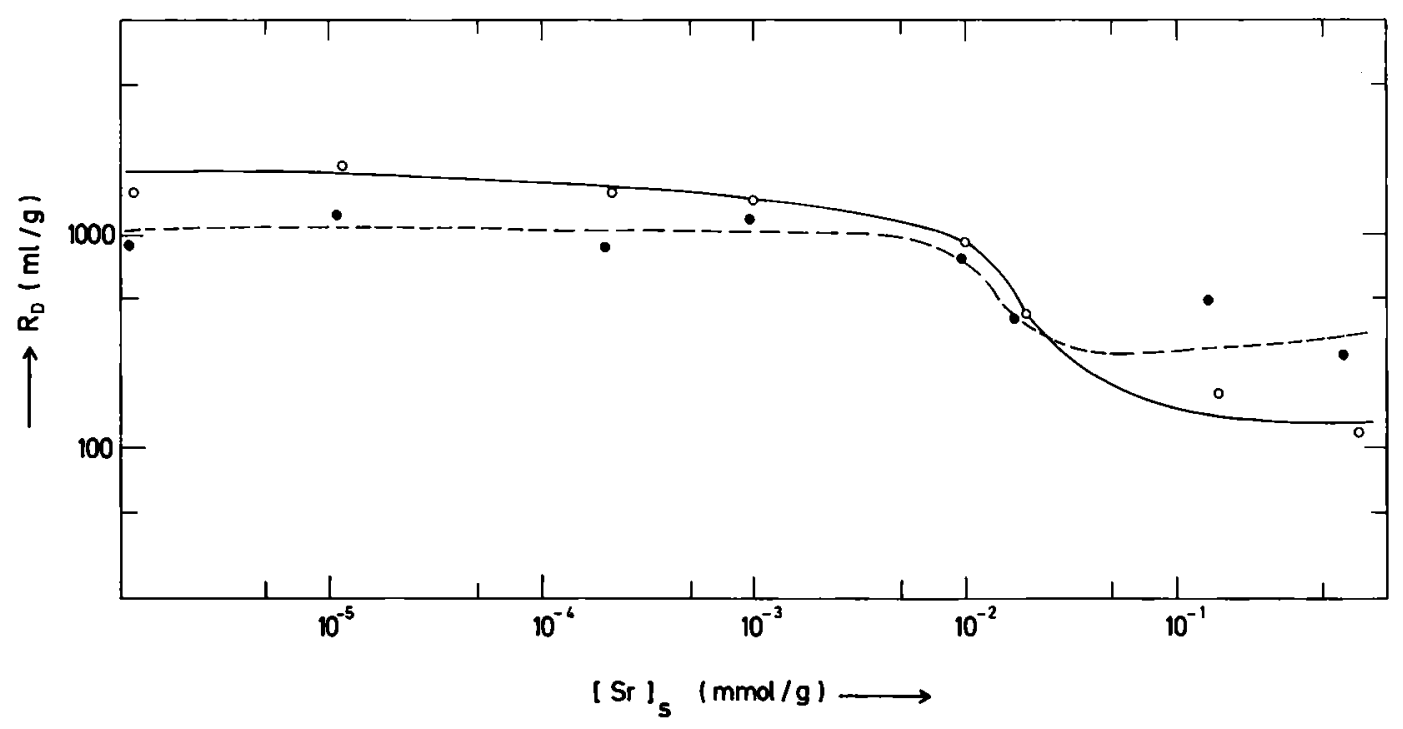

Fig. 3. The change of $R_{D}$ values with strontium ion loading, for Rasadiye Clay (Montmorillonite). Particle size $=10-20 \mu \mathrm{m}$.

$$
\text { - Adsorption }
$$

for Cs. It is observed that steady state was reached in about 4-7 days. Similar behaviour was observed for $\mathrm{Sr}$, however, the time to reach steady state was somewhat longer, 7-11 days. Increase in $R_{D}$ with decreasing particle size suggest mainly a surface phenomenon.

The rate of adsorption was found to vary from 0.47 to $9.90 \mathrm{ml} / \mathrm{g} \cdot \mathrm{h}$ depending on the cation, its concentration, the particle size, the type of clay, $\mathrm{pH}$ of solution, and the speed of shaking. Other factors such as solid/solution $(100 \mathrm{mg} / 10 \mathrm{ml}$ ) ratio and temperature (room temperature) were the same in all experiments. In order to study the effect of shaking, two different shaking machines were used. A longitudinal shaking type with a shaking frequency of 250 strokes/min, and a circular shaking type with a speed of $150 \mathrm{rpm}$. No difference in the rate of adsorption was observed. Smaller size particles $(<10$ $\mu \mathrm{m}$ ) did not show any change in $R_{D}$ values. In the case of larger size particles $(10-20 \mu \mathrm{m})$, somewhat higher $R_{D}$ values were observed with the faster longitudinal shaker, suggesting some degree of abrasion during shaking.

The desorption behaviour of $\mathrm{Sr}$ is illustrated in Fig. 2 . The figure suggests a rather complicated desorption 


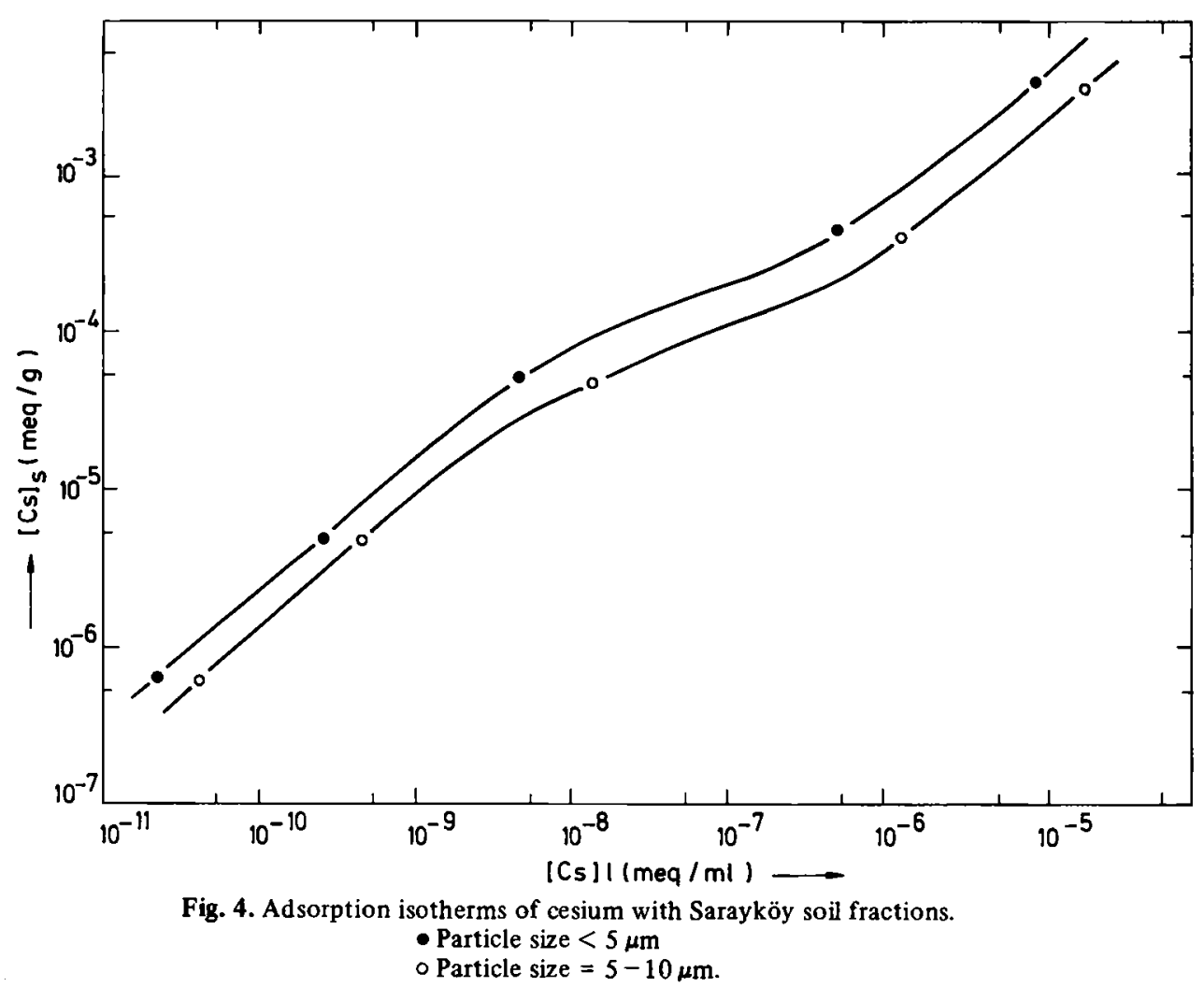

mechanism. Considerable initial rapid desorption seems to be followed by a readsorption until steady stat is reached. Similar behaviour was observed in the desorption of Cs.

The variation of the distribution ratio, $R_{D}$, as a function of $\mathrm{Sr}$ ion concentration in the solid phase is shown in Fig. 3. It is seen that at lower Sr loadings $\left(<10^{-2} \mathrm{mmol}\right.$ /g) the desorption was displaced to lower distribution ratios, whereas at higher Sr loadings $\left(.10^{-1} \mathrm{mmol} / \mathrm{g}\right)$ it is displaced to higher $R_{D}$ values. However, the shape of the adsorption curve was preserved in desorption. In the case of $\mathrm{Cs}^{+}$ion sorption on kaolinite the results for adsorption and desorption were quite similar, indicating a reversible sorption process. The shapes of the curves suggest the existence of at least two types of adsorption and/or exchange mechanism. One type taking place at high ion con centrations and the other at low ion concentrations.

The sorption isotherms of Cs cation on Sarayköy soil fractions are shown in Fig. 4. It is seen that the isotherms are not linear. Similar behaviour was observed in the sorption of $\mathrm{Sr}^{2+}$ and $\mathrm{Cs}^{+}$on the clay and soil fractions. The sorption of $\mathrm{Sr}$ on Kaolinite clay was the only exception. It gave a linear sorption isotherm, suggesting one type of sorption mechanism. The $\mathrm{Cs}$ and $\mathrm{Sr}$ concentrations present in the clay minerals and soil fractions at the beginning of the sorption studies were estimated to be low and were not taken into account.

Table 2 summarizes the steady state values of the distribution coefficient, $R_{D}$, for different types of clay and soil fractions used on this work. The high $R_{D}$ values for soil fractions, particularly in the case of Cs sorption is striking. This may be due to the presence of organic components, such as humic acids, in the soil fractions.
Table 2. Steady state values of $R_{D}$ for clay and soil fractions used in this work

\begin{tabular}{lcc}
\hline \multicolumn{1}{c}{$\begin{array}{c}\text { Solid material } \\
\text { used }\end{array}$} & \multicolumn{2}{c}{$R_{D}(\mathrm{ml} / \mathrm{g})$} \\
\cline { 2 - 3 } & $\mathrm{Sr}^{++}$ & $\mathrm{Cs}^{+}$ \\
\hline $\begin{array}{l}\text { Mihalliccik Clay } \\
\text { (Kaolinite) }\end{array}$ & 120 & 2000 \\
$\begin{array}{l}\text { Resadiye Clay } \\
\text { (Montmorillonite) }\end{array}$ & 1500 & 3500 \\
Sarayköy Soil & 400 & 27000 \\
\hline
\end{tabular}

\section{Conclusions}

The observed sorption behaviours of $\mathrm{Sr}$ and $\mathrm{Cs}$ on montmorillonite and kaolinite type clay minerals and on soil fractions were found to be a function of the chemical composition of these species, the water composition and the properties of the solid sorbent. It was found that generally montmorillonite clay adsorbs $\mathrm{Cs}$ and $\mathrm{Sr}$ much more than kaolinite clay due to their different structural characteristics.

The sorption isotherms are found to be mostly nonlinear. The distribution coefficients increased with decreasing grain size, suggesting mainly surface sorption.

The adsorption/desorption process was found to be reversible for Cs sorption on clays, whereas Cs sorption on Sarayköy soil and Sr sorption on clay and soil were only partially reversible.

\section{References}

1. DLOUGhy, A.: Movement of Radionuclides in the Aerated Zone, in Disposal of Radioactive Wastes into the Ground. IAEA, Vienna 1967, p. 241. 
2. BRUGGENWERT, M. G. M., KAMPHORST, A.: Survey of Experimental Information on Cation Exchange in Soil Systems. In: Soil Chemistry (G. H. BOLT, ed.) B. PhysicoChemical Models, Elsevier, Amsterdam 1979, p. 141.

3. PALMER, D. A., SHIAO, S. Y., MEYER, R. E., WETHINGTON, J. A.: Adsorption of Nuclides on Mixtures of Minerals, J. Inorg. Nucl. Chem. 43, 3317 (1981).

4. TORSTENFELT, B., ANDERSSON, K., ALLARD, B.: Sorption of Strontium and Cesium on Rocks and Minerals, Chem. Geol. 36, 123 (1982).

5. BUNZL, K., SCHULTZ, W.: Distribution Coefficients of ${ }^{137} \mathrm{Cs}$ and ${ }^{85} \mathrm{Sr}$ by Mixtures of Clay and Humic Material, J. Radioanal. Nucl. Chem. 90, 23 (1985).

6. ALLARD, B., ITTNER, T., TORSTENFELT, B.: Migration of Trace Elements into Water-Exposed Natural Fissure Surfaces of Granitic Rock, Chem. Geol. 49, 31 (1985).

7. TORSTENFELT, B.: Migration of the Fission Products Strontium, Technetium, Iodine and Cesium in Clay, Radiochim. Acta 39, 97 (1986).
8. GRUTTER, A., VON GUNTEN, H. R.: Sorption, Desorption und Austausch von Caesium an quartaren glaziofluvialen Schotterböden und Tonmineralien. PTB-SI-14, Proc. Chemie und Migrationsverhalten der Aktionoide und Spaltprodukte in natürlichen aquatischen Systemen. Herausg. J. I. KIM, E. WAR NECKE, München 1987, p. 140.

9. GRUTTTER, A., VON GUNTEN, H. R., RÖSSLER, E.: Sorption, desorption and isotope exchange of Cesium $\left(10^{-9}-10^{-3} \mathrm{M}\right)$ on Chlorite, Clays Clay Miner. 34, 677 (1986).

10. ERTEN, H. N., A KSOYOG LU, S., GÖKTURK, H. Sorption/Desorption of Cs on Clay and Soil Fractions from Various Regions of Turkey, 5 th Symposium on Environmental Radiochemical Analysis, 1 - 3 October 1986 Harwell, U. K., and Sci. Tot. Envir. 69, 269 (1988).

11. A KSOYOGLU, S., GOKT UR K, H., ERTEN, H. N.: Neutron Activation Analy sis of Turkish Clays, J. Radioanal. Nucl. Chem. Lett. 104, 97 (1986). 
Brought to you by | Bilkent University

Authenticated

Download Date | 12/7/18 8:06 PM 